Consensus and Debate in Salazar's Portugal carries out this challenging task brilliantly.

Anna M. Klobucka

University of Massachusetts Dartmouth

\title{
Frier, David. The Novels of José Saramago: Echoes from the Past, Pathways into the Future. Cardiff: University of Wales Press, 2007.
}

Given the media attention surrounding both the literary production and the intellectual persona of the late José Saramago - a notoriety garnered as much by the author's provocative statements on socio-political and religious issues as by the numerous literary prizes he was awarded throughout the years - we must welcome critical analyses of his work that pierce through the obfuscating limelight and address in a rigorous way the literary and philosophical presuppositions undergirding his oeuvre. The pigeonholing of Saramago as an enemy of religion, an intolerant communist and a betrayer of his country after moving to the Canary Islands; or as an anti-globalization hero, a paladin of human rights, and one of the last true upholders of the values of the 1974 Revolution-depending on the political colors of the critic in question - polarizes his potential readership and ultimately leads to a neutralization of both the literary innovations and the real social challenges highlighted in his texts, as these get buried under layers of media scandal. A case in point was the controversy surrounding the publication of the author's last novel Caim (2009), which triggered a misguided public debate about the text's attacks on religion, Saramago's supposed anti-Semitism, and other such platitudes, while all but evading a serious consideration of the literary merits (and faults) of the narrative. The author's recent death again sparked a fierce debate about his literary and intellectual legacy and, even as many paid homage, in Portugal and abroad, to the writer's contributions to Portuguese and world literature, this tribute was marred 
by the conspicuous absence of Portuguese president Cavaco Silva from the ceremonies marking Saramago's passing, and by the uncharitable epitaph published on this occasion in the Vatican's Osservatore Romano, where the novelist was accused of having been a "populist extremist." David Frier's study of Saramago's novels is one of several critical readings of the writer's work (see also, for instance, Maria Alzira Seixo's Lugares da Ficção em José Saramago [INCM, 1999], Eduardo Calbucci's Saramago: Um Roteiro para os Romances [Ateliê Editorial, 1999], or the issue of Portuguese Literary and Cultural Studies devoted to Saramago [6, Spring 2001]) that distance themselves from the superficial commentaries on his texts shaped by the public image of the author his vociferous critics and proponents have created. Frier's book contributes to a sober evaluation of Saramago's literary legacy and to a clearer understanding of the topics that run through his writings, thus leading to a revitalization of the sharp literary and political insights of his work.

Frier felicitously opted for a thematically organized discussion of Saramago's novels that loosely follows the chronological order of their publication, a structure that enables him to foreground the thematic unity of the author's corpus while underlining major stylistic shifts in his work. The book opens with an extended introduction, directed mostly at those unacquainted not only with Saramago's writings but also with Portuguese history and literature, where Frier attempts the impossible task of summarizing the main cultural references present in the novelist's narratives. The three main chapters, however, are in-depth, painstakingly researched analyses of some of the central topoi of Saramago's literary output. Chapter One focuses mainly on the criticism of socio-economic imbalances and the exploitation of the underprivileged by the establishment in two of the author's earlier novels, Levantado do Chão (1980) and Memorial do Convento (1982). In Chapter Two, Frier addresses the struggle of individual characters against the all-pervasive power structures that strive to ensnare them, paying particular attention to the novels Jangada de 
Pedra (1986), História do Cerco de Lisboa (1989) and Evangelho Segundo Jesus Cristo (1991). Finally, Chapter Three reflects about the representation of human finitude in Saramago's works, with the novel As Intermitencias da Morte (2005) as its point of departure, and contrasts the lived engagement with socio-political circumstances that the author propounds in many of his writings to the half-life of one of his most memorable characters, Fernando Pessoa's heteronym Ricardo Reis, who, like many intellectuals of his generation, failed to rise up against totalitarianism in $O$ Ano da Morte de Ricardo Reis (1984).

One of the merits of Frier's study is that it discusses Saramago's oeuvre as a whole and, even though the table of contents does not explicitly mention all the published novels, they are all addressed in one way or another throughout the book, which allows the reader to form a well-rounded picture of the novelist's literary imaginary. Frier is also particularly attentive to intertextuality, a device employed by Saramago to create a thick web of literary and historical references often alluded to mockingly or ironically by a playful narrator. Frier meticulously enumerates the intertextual echoes of key passages in order to show how the writer appropriates the ugly underside of a conservative and oppressive tradition that is handed down unquestioningly in society, all the while rewriting parts of this tradition by embedding it in his texts.

Something almost entirely absent from Frier's analysis, however, is an engagement with the theoretical and philosophical underpinnings of Saramago's work. The fleeting references to the Gramscian theorization of the role of the intellectual in Chapter Two leave a number of questions unanswered. If, as Frier argues, Saramago sketches - with Blimunda in Memorial do Convento and Lídia in O Ano da Morte de Ricardo Reis-characters akin to what Gramsci defined as "organic intellectuals," one would need to reflect about the problematic conditions of possibility for the emergence of such intellectuals in the novels, as they are associated with the universalization of a revolutionary (proletarian) class, something that did not 
come to pass in either of the time periods described in these texts. In Chapter One, Frier acknowledges that Saramago privileges Marxist ideologemes (31), but the discussion of economic relations, resistance, alienation and power (sections 2, 4, 5 and 6 of the chapter, respectively) barely includes any allusions to the Marxian theory where these terms originated, let alone an account of how Saramago creatively refashions Marxist thought in his fiction. Similarly, in Chapter Three, the comments on inauthentic existence and the inexorability of death beg for a reference to Martin Heidegger's groundbreaking reflections on precisely these topics in his magnum opus Being and Time.

Frier's study is a thorough, well-researched analysis of some of the crucial themes at work in Saramago's literary production. The book offers a comprehensive portrayal of the author's novels and refers to the most relevant secondary sources on the author, thus serving both as a good road map for those venturing into Saramago's fictional world for the first time and as an enlightening companion for readers familiar with the writer's texts. Despite the absence of a meaningful engagement with the obvious philosophical implications of Saramago's work, Frier's readings of his novels are a valuable contribution to a field otherwise so saturated with white noise.

Patrícia Vieira Georgetown University

Eiras, Pedro, ed. Jovens Ensaístas Lêem Jovens Poetas. Porto: Deriva, 2008.

É com uma assinalável intensidade que temos vindo a assistir, nos últimos decénios, a uma proliferação de trabalhos sobre a chamada novíssima poesia portuguesa contemporânea (período que abarca, grosso modo, os anos 90 e a primeira década do século XXI). Entre os inúmeros estudos que se debruçam sobre as novas poéticas, contam-se as seguintes contribuições: 9 Poetas para o Século XXI 